\title{
Updating public participation in IWRM: A proposal for a focused and structured engagement with Catchment Management Strategies"
}

\author{
Derick du Toit* and Sharon Pollard \\ Association for Water \& Rural Development (AWARD), Private Bag X420, Acornhoek 1360, South Africa
}

\begin{abstract}
Despite the strong emphasis on public participation in the National Water Act (NWA), South Africa has yet to implement a comprehensive and functional approach to public engagement at the level of Water Management Areas. Part of the problem is that actual requirements are not explicitly articulated anywhere. This has led to the situation where public participatory processes are poorly conceptualised, misdirected and often perceived as confusing by stakeholders. 'Participation fatigue' is the consequence of this accompanied by a growing frustration with the implementation of the content of the Act. The intention for decentralised democratic water resources management is consequently seriously jeopardised if the public participation processes are not clearly presented in the public domain.

In this paper we draw on a number of sources, namely a national pilot integrated catchment management programme called the Save the Sand Project initiated in the north-eastern part of SA, a Water Research Commission project on public participation and a DWAF project that funded the exploration of public participation in the Sand River Catchment. The latter (2005 -2007) supported a better understanding of public participation processes and dynamics in a high-density rural catchment, the findings from which are reported here. Additionally this paper is referenced against the current discourse on public participation in water resources aimed at elucidating public participation in integrated water resource management (IWRM) in South Africa. The focus of the work reported in this paper is specifically on the development and implementation of catchment management strategies as the locus of decentralised, democratised, participatory water resource management.

In this paper we start out by discussing how complexities surrounding public engagement might present newly established catchment management agencies (CMAs) with serious challenges and then move on to a proposed framework for focusing public engagement on specific IWRM tasks. The framework outlines tasks where multi-stakeholder platforms collaboratively design strategic water management actions that are assembled as the catchment management strategy (CMS), a statutory obligation for CMAs.
\end{abstract}

Keywords: public participation, catchment management strategies, National Water Act, integrated water resource management

\section{IWRM in the South African context}

Integrated water resource management (IWRM) with its proposed institutional arrangements as set out in the National Water Act (NWA, 1998) provides the broad context for the engagement of the general public in water resource management. Once CMAs are established they are expected to manage water in collaboration with local stakeholders. The NWA makes provision for a number of stakeholder platforms (catchment management forums - CMFs and catchment management committees - CMCs) where IWRM can be negotiated at the level of a water management area. A wealth of documentation, guidelines and research literature (DWAF, 2000; 2001a-d; 2004a,b; WRC, 2003; 2004a-c) deals with various aspects of the establishment and functioning of these platforms. The platforms are intended

* Revised version. Originally presented at the International Conference on Integrated Water Resource Management (IWRM) entitled: Lessons from Implementation in Developing Countries which took place from 10 to 12 March 2008 in Cape Town, South Africa, at The Cape Town International Convention Centre.

* To whom all correspondence should be addressed.

+2715 793 7500, Fax +2715 793 7509;

e-mail: derick@award.org.za to be more than places where stakeholders defend vested interests in water resources. They are platforms where decisions are taken and collaborative actions are designed in order to strategically manage water resources for and by the inhabitants of a WMA. South Africa has yet to implement a comprehensive and functional approach to stakeholder engagement at the level of Water Management Areas. One of the most important challenges relates to focusing the interactions on specific IWRM tasks (Du Toit et al., 2005). As multiple stakeholder environments are potentially conflictual it is essential that tasks are clearly articulated and well presented at such forums in order to appropriately direct interactions.

In this paper we draw on a number of sources, namely a national pilot integrated catchment management programme called the Save the Sand Project initiated in the north-eastern part of SA (Pollard et al., 1998; Pollard and Du Toit, 2004; Du Toit, 2005), a Water Research Commission project on public participation (Lotz-Sisitka and Burt, 2005; Du Toit et al, 2005), Catchment Management Strategy Guidelines (DWAF, 2007), and a DWAF project that funded the exploration of public participation in the Sand River Catchment. The latter (2005-2007) supported a better understanding of public participation processes and dynamics in a high-density rural catchment, the findings from which are reported here. Additionally this paper is referenced against the current discourse 
on public participation in water resources aimed at elucidating public participation in integrated water resource management (IWRM) in South Africa. The focus of the work reported in this paper is specifically on the development and implementation of Catchment Management Strategies as the locus of decentralised, democratised, participatory water resource management.

\section{An enabling policy environment is not enough}

Whilst we recognise the importance of an enabling legislative and policy environment, we maintain that these are not sufficient to support the development of meaningful public participation in IWRM. The National Water Policy (1997), NWA (1998), NWRS (2001), and the Guidelines for CMS (2007) explicitly outline the need for public engagement in IWRM. In a WRC report (Du Toit et al., 2005) the authors outlined a proposal for task-oriented public participation in IWRM. However it is only with the development of the CMS guidelines (DWAF, 2007) that a clear and practical guide as to how the public could be engaged in the various tasks associated with IWRM is presented. In this paper we take the issue further by proposing clear and specific public participatory actions for each step of IWRM as outlined by the CMS guideline. Additional steps in this regard need to include who is going to perform what action and when it should occur. Before we do this however, we provide the basis for motivating for a more focused and directed form of public participation in IWRM.

\section{Public participation in IWRM: What is likely to go wrong?}

Over the duration of the past 5 years the Association for Water and Rural Development (AWARD) and the Kat River Project, Rhodes University (see Burt et al., 2007) have engaged various stakeholders in participatory IWRM and capacity-development programmes. Based on these experiences we have extracted what are likely to be problem areas for IWRM processes in general in the hope that they can inform future public participation processes. An in-depth discussion of these is beyond

\begin{tabular}{|c|c|}
\hline \multicolumn{2}{|c|}{$\begin{array}{l}\text { TABLE } 1 \\
\text { Summary of challenges facing IWRM processes - based on the experiences of the Save the Sand Project } \\
\text { (Pollard et al, 1998) and the Kat River Project (Burt, 2005; Burt et al., 2005; Burt et al., 2007) }\end{array}$} \\
\hline Issue & Consequences \\
\hline \multicolumn{2}{|c|}{ 1. Public participation in IWRM not planned in a holistic way } \\
\hline $\begin{array}{l}\text { Tasks of IWRM not clearly communicated or understood by the } \\
\text { public }\end{array}$ & $\begin{array}{l}\text { Public not sure of what IWRM entails and confused as to what is expected } \\
\text { of them }\end{array}$ \\
\hline $\begin{array}{l}\text { Sequence and procedure of engagement with tasks not clearly } \\
\text { communicated with public }\end{array}$ & $\begin{array}{l}\text { Public confused with the sequence of engagement, no continuity, tasks poorly } \\
\text { co-ordinated and performed - weak outcomes }\end{array}$ \\
\hline \begin{tabular}{|l|l} 
Process of IWRM is new and unfamiliar &
\end{tabular} & $\begin{array}{l}\text { Capacity and skills for engaging with IWRM process does not exist with } \\
\text { resultant poor or rudimentary outcomes }\end{array}$ \\
\hline $\begin{array}{l}\text { Overlap of democratic channels for communication and participa- } \\
\text { tion }\end{array}$ & $\begin{array}{l}\text { Local government (community development forums) and CMA platforms } \\
\text { (catchment management forums) conflict with each other and create redundant } \\
\text { engagement and confusion }\end{array}$ \\
\hline $\begin{array}{l}\text { 'Stakeholder fatigue' stemming from too many workshops, meet- } \\
\text { ings and public gatherings with repetition of agendas and content }\end{array}$ & $\begin{array}{l}\text { Public lose interest and commitment to the public participation process and } \\
\text { fail to attend future gatherings }\end{array}$ \\
\hline $\begin{array}{l}\text { No reporting and feedback associated with meetings and therefore } \\
\text { no record of engagement and decisions }\end{array}$ & $\begin{array}{l}\text { Results in a loss of continuity and sustained engagement. Representatives do } \\
\text { not report back to institutions and the opportunity for learning is lost }\end{array}$ \\
\hline $\begin{array}{l}\text { Incoherent presentation of IWRM tasks, overlap and duplication } \\
\text { of tasks (e.g. visioning and water allocation planning) }\end{array}$ & $\begin{array}{l}\text { Results in the public having to repeat tasks or aspects of tasks with resultant } \\
\text { frustration and fatigue }\end{array}$ \\
\hline $\begin{array}{l}\text { Project approach: IWRM tasks broken into series of independent } \\
\text { projects }\end{array}$ & $\begin{array}{l}\text { Projects operating independently result in fragmented and disparate } \\
\text { approach }\end{array}$ \\
\hline \multicolumn{2}{|c|}{ 2. Different levels of engagement not clarified } \\
\hline $\begin{array}{l}\text { Stakeholders not clear as to the type and level of engagement } \\
\text { required at a particular stage of IWRM }\end{array}$ & Stakeholders unclear of what is expected of them in participation process \\
\hline $\begin{array}{l}\text { ‘Costly collaboration': collaborative action in costly in terms of } \\
\text { time and resources. Collaborative management requires high lev- } \\
\text { els of capacity and is not necessary for each step of IWRM. }\end{array}$ & $\begin{array}{l}\text { An over-emphasis on collaborative participation is costly and likely to lead to } \\
\text { fatigue, especially if it is not essential to the process. }\end{array}$ \\
\hline $\begin{array}{l}\text { Diversity and preparedness: different groups of stakeholders are } \\
\text { prepared differently for the tasks of IWRM }\end{array}$ & $\begin{array}{l}\text { Skewed and inequitable ability to participate. Particularly important in the } \\
\text { case of previously disadvantaged groups }\end{array}$ \\
\hline $\begin{array}{l}\text { Power gradients (language and resources): this relates to the point } \\
\text { above but refers specifically to access to language and material } \\
\text { resources }\end{array}$ & $\begin{array}{l}\text { Poorly resourced participants are at a disadvantage in the public participation } \\
\text { process and therefore not able to participate equally in the decision taking } \\
\text { processes (water allocation planning, resource classification etc.) }\end{array}$ \\
\hline $\begin{array}{l}\text { Geographical issues and access. Public participation processes } \\
\text { tend to be organised near larger municipal centres }\end{array}$ & $\begin{array}{l}\text { Rural populations are excluded from the process by virtue of poor access and } \\
\text { having to absorb the costs of transport }\end{array}$ \\
\hline \multicolumn{2}{|c|}{ 3. Procedures too elaborate and sophisticated for initial stages of public engagement } \\
\hline $\begin{array}{l}\text { Dense, lengthy and complicated procedures: some tasks of IWRM } \\
\text { (i.e. resource classification) are highly technical and complicated }\end{array}$ & $\begin{array}{l}\text { Diverse, non-specialist groups may find such procedures too difficult espe- } \\
\text { cially in the initial stages of participation. Such processes need to be simplified } \\
\text { and capacity building is required before the public can engage }\end{array}$ \\
\hline $\begin{array}{l}\text { Context and emergence: the IWRM process must be grounded in a } \\
\text { specific context for stakeholders to make appropriate meaning }\end{array}$ & $\begin{array}{l}\text { This is a process that takes time and requires adequate preparation. Poorly } \\
\text { prepared public meetings, lack of data and reference to local contextual exam- } \\
\text { ples weakens public participation process and decision making }\end{array}$ \\
\hline $\begin{array}{l}\text { Public engagement is not focused on principles but on technical } \\
\text { details }\end{array}$ & $\begin{array}{l}\text { Over-emphasis of technical details can be intimidating and discouraging of } \\
\text { participatory practices }\end{array}$ \\
\hline
\end{tabular}


the scope of this paper; however, the summary provided in Table 1 provides the point of departure for the development of a proposal that is outlined in the second part of the paper. (In the table we present three broad categories of challenges and we break these down into specific issues and their associated consequences).

The obstacles outlined in Table 1 imply that IWRM requires substantial mediation and structure when taken into the public domain. We maintain that the three broad categories captured in the table are of such significance to the process of public participation that should they not be addressed the entire endeavour stands to be jeopardised. In the sections that follow we provide a proposed framework that could assist IWRM practitioners and CMAs resolve some of the issues related to the three problem areas outlined in the table.

\section{The public participation spectrum: Establish- ing the 'right' type of public participation at the 'right' time}

The CMA is faced with the huge challenge of having to design a process that facilitates appropriate engagement in IWRM, at the appropriate times. In this section we provide a framework that could assist CMAs in this regard.

The International Association for Public Participation $\left(\right.$ IAP $\left.^{2}\right)$ has identified different types of public participation (Table 2) which they call a spectrum. The IAP ${ }^{2}$ lists 'Empower' as an autonomous decision making process as part of the Participation Spectrum. However, this option does not exist within the South African legal context. The public is provided with the opportunity to participate in a collaborative manner but not to take autonomous decisions that the CMA must implement. The 'empower' column has been omitted. We see that the level of involvement increases towards the right of the table and there is a general trend from provision of information to collaborative decision-making. This does not imply that one is more important than the other. The challenge is to select the appropriate level of participation for a particular task. In this section we will identify the tasks and provide a framework for the 'right' type of participation to be supported by drawing on the public participation spectrum developed by the IAP ${ }^{2}$.

\section{The CMS - the basis for structuring public engagement}

The democratisation and decentralisation of water resource management to more regional and localised levels of water management areas places a responsibility on localised water management institutions such as the CMA. The challenge for the CMA is to engage stakeholders in strategic planning that recognises the need to plan for water security through the development of CMSs. The CMS guidelines (DWAF, 2007) provide clear reasons for involving the public in the development and implementation of a CMS. In summary these include the need to:

- Serve as broad a range of interests as possible

- Improve data or information gathering, identify gaps in data or information and identify sources of data or information in the future

- Provide transparency and accountability regarding both decisions taken and the process by which decisions were taken in developing the CMS

- Build a broad base of commitment to options by creating an environment in which there is meaningful discussion of benefits, risks, and costs of options, and that consequently provides a basis for informed consent to recommendations

\begin{tabular}{|c|c|c|c|}
\hline \multicolumn{4}{|c|}{$\begin{array}{l}\text { TABLE } 2 \\
\text { The Public Participation Spectrum. Understanding the table contents helps with } \\
\text { developing the plans for participatory practice and provides the basis for the 'how' } \\
\text { and 'why' of public engagement (adapted from the International Association for Public } \\
\text { Participation I AP'. 2000; All rights reserved). }\end{array}$} \\
\hline I NFORM & CONSULT & I NVOLVE & COLLABORATE \\
\hline $\begin{array}{l}\text { Public participation } \\
\text { goal: }\end{array}$ & $\begin{array}{l}\text { Public participation } \\
\text { goal: }\end{array}$ & $\begin{array}{l}\text { Public participation } \\
\text { goal: }\end{array}$ & $\begin{array}{l}\text { Public participation } \\
\text { goal: }\end{array}$ \\
\hline $\begin{array}{l}\text { To provide the public with } \\
\text { balanced information to } \\
\text { assist them in } \\
\text { understanding the } \\
\text { problem, opportunities, } \\
\text { solutions and alternatives }\end{array}$ & $\begin{array}{l}\text { To obtain public feedback } \\
\text { on analysis, alternatives } \\
\text { and decisions }\end{array}$ & $\begin{array}{l}\text { To work directly with the } \\
\text { public throughout the } \\
\text { process to ensure that } \\
\text { public concerns are } \\
\text { consistently understood } \\
\text { and considered }\end{array}$ & $\begin{array}{l}\text { To partner with the public } \\
\text { in each aspect of the } \\
\text { decision-making process } \\
\text { including the development } \\
\text { of alternatives and the } \\
\text { identification of preferred } \\
\text { solutions }\end{array}$ \\
\hline Promise to the public: & Promise to the public: & Promise to the public: & Promise to the public: \\
\hline We will keep you informed & $\begin{array}{l}\text { We will keep you informed, } \\
\text { listen to and acknowledge } \\
\text { concerns and aspirations, } \\
\text { provide feedback on how } \\
\text { public input influenced the } \\
\text { decision }\end{array}$ & $\begin{array}{l}\text { We will work with you to } \\
\text { ensure that your concerns } \\
\text { and aspirations are directly } \\
\text { reflected in the alternatives } \\
\text { developed and provide } \\
\text { feedback on how the } \\
\text { public input influenced the } \\
\text { decisions }\end{array}$ & $\begin{array}{l}\text { We will look to you for } \\
\text { direct advice and } \\
\text { innovation in formulating } \\
\text { solutions and incorporate } \\
\text { your advice and } \\
\text { recommendations into the } \\
\text { decisions to the maximum } \\
\text { extent possible }\end{array}$ \\
\hline \multicolumn{4}{|l|}{ Example techniques } \\
\hline $\begin{array}{l}\text { - } \text { Fact Sheets } \\
\text { - } \text { - Opeb sites } \\
\text { - } \text { Press releases } \\
\text { - } \\
\text { - } \text { Medvertisements } \\
\end{array}$ & $\begin{array}{l}\text { - Public comment } \\
\text { - Focus groups } \\
\text { - Surveys } \\
\text { - Public meetings }\end{array}$ & $\begin{array}{l}\text { - Workshops } \\
\text { - Polling } \\
\text { - Meetings }\end{array}$ & $\begin{array}{l}\text { - } \text { Citizen advisory } \\
\text { committees } \\
\text { - } \text { Forums } \\
\text { - Consensus building } \\
\text { - Participatory decision- } \\
\text { making }\end{array}$ \\
\hline \multicolumn{4}{|c|}{ I ncreasing level of public engagement } \\
\hline
\end{tabular}




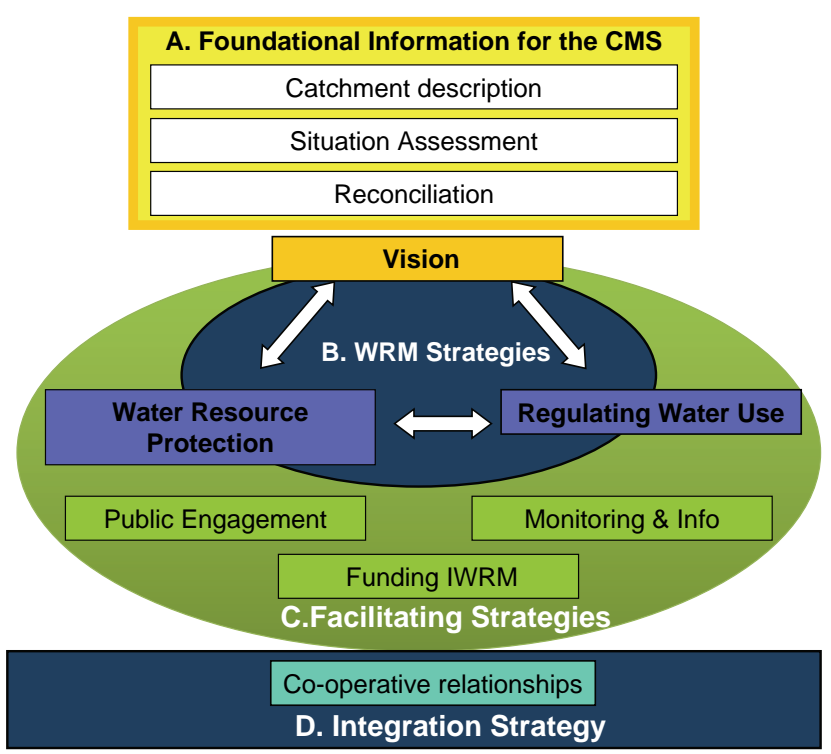

Figure 1

The framework for IWRM and hence the CMS in South Africa (DWAF, 2007 adapted from DWAF 1999). Clusters of contextual information and sub-strategies for the CMS fall into four parts:

\section{$A, B, C \& D$}

- Ensure greater sustainability of implementation by involving affected parties in a positive manner.

In order to address these aims a framework for the development of a CMS is provided in Fig. 1 (DWAF, 2007). This framework is discussed in more detail by Pollard and Du Toit (2008) in more detail and should be read in conjunction with this contribution. For purposes of efficiency only aspects of the framework pertinent to the discussion of public participation will be described in this section.

The framework is conceptualised as four clusters of strategic plans, Parts A-D, which collectively comprise the CMS. A number of these deal specifically with the 'business' of IWRM whilst others facilitate the operating of the CMA, roll-out and operation of the strategies. The parts of the CMS are described below.

\section{Part A: Important foundational information}

Part A does not involve strategy development per sé but provides the foundation for strategic action. It is important that the public has an important understanding of the contextual issues before engaging in strategic planning.

Part B: Water Resource Management sub-strategies

Once a vision has been set for a WMA, two key strategic areas have been identified by the NWRS to achieve the vision. Importantly, these two areas, known as Resource Directed Measures (RDM) and Source Directed Controls (SDC), are the overarching strategies for IWRM in South Africa. The RDM is directed at protecting the water resource base whilst SDC constitute regulations for water use.

Part C: Facilitating sub-strategies

The facilitating strategies are not directly linked to IWRM. Rather they are the 'oil' that keeps the 'engine' of IWRM going. In other words without strategic plans for stakeholder engagement and communication,

\begin{tabular}{|c|c|c|c|}
\hline \multicolumn{4}{|c|}{$\begin{array}{c}\text { TABLE } 3 \\
\text { Breakdown of the parts of the CMS with its associated tasks and appropriate levels of public participation }\end{array}$} \\
\hline Part of the CMS & Task area & Rationale & $\begin{array}{l}\text { Types of } \\
\text { participation }\end{array}$ \\
\hline \multirow[t]{4}{*}{$\begin{array}{l}\text { Part A: Background } \\
\text { information and } \\
\text { situation assessment }\end{array}$} & Situation description & $\begin{array}{l}\text { The involvement of the public in this stage of the process is critical in } \\
\text { that it is likely to reveal divergent views of the resource as well areas } \\
\text { of potential conflict. }\end{array}$ & \begin{tabular}{|l|l} 
Inform \\
Involve \\
Collaborate
\end{tabular} \\
\hline & Situation assessment & $\begin{array}{l}\text { This stage enables the public to collectively assess the status of the } \\
\text { resource prior to setting a vision. }\end{array}$ & $\begin{array}{l}\text { Inform } \\
\text { Involve } \\
\text { Collaborate }\end{array}$ \\
\hline & Reconciliation & $\begin{array}{l}\text { Assessing the balance between availability and requirements for a } \\
\text { particular catchment }\end{array}$ & $\begin{array}{l}\text { Inform } \\
\text { Involve } \\
\text { Collaborate }\end{array}$ \\
\hline & Visioning & The collaborative vision for managing the resource is set at this stage & $\begin{array}{l}\text { Inform } \\
\text { Involve } \\
\text { Collaborate }\end{array}$ \\
\hline \multirow[t]{2}{*}{$\begin{array}{l}\text { Part B: WRM } \\
\text { strategies }\end{array}$} & $\begin{array}{l}\text { Resource protection } \\
\text { strategies }\end{array}$ & $\begin{array}{l}\text { Public involvement in the classification of the resource, and negotia- } \\
\text { tion of resource quality objectives }\end{array}$ & $\begin{array}{l}\text { Inform } \\
\text { Involve } \\
\text { Consult } \\
\text { Collaborate } \\
\end{array}$ \\
\hline & $\begin{array}{l}\text { Water use regulation } \\
\text { strategies }\end{array}$ & $\begin{array}{l}\text { Public involved in drafting of water allocation plan, licence applica- } \\
\text { tions and compliance with water use conditions }\end{array}$ & $\begin{array}{l}\text { Inform } \\
\text { Collaborate }\end{array}$ \\
\hline \multirow[t]{3}{*}{$\begin{array}{l}\text { Part C: Facilitating } \\
\text { strategies }\end{array}$} & $\begin{array}{l}\text { Public participation, } \\
\text { communication and } \\
\text { capacity building proc- } \\
\text { esses established }\end{array}$ & $\begin{array}{l}\text { A strategy for establishing and maintaining functioning platforms } \\
\text { negotiated. Communication and capacity building processes estab- } \\
\text { lished. }\end{array}$ & Involve \\
\hline & $\begin{array}{l}\text { Information manage- } \\
\text { ment and monitoring }\end{array}$ & $\begin{array}{l}\text { Protocols for monitoring and information management established } \\
\text { with the assistance and input from stakeholders }\end{array}$ & \begin{tabular}{|l|l} 
Involve \\
Consult \\
Collaborate \\
\end{tabular} \\
\hline & Financial arrangements & $\begin{array}{l}\text { Financial arrangement, especially water resource management } \\
\text { charges established with public involvement and captured in the CMS }\end{array}$ & $\begin{array}{l}\text { Involve } \\
\text { Consult }\end{array}$ \\
\hline $\begin{array}{l}\text { Part D: Co-operative } \\
\text { governance and insti- } \\
\text { tutional relationships }\end{array}$ & $\begin{array}{l}\text { Institutional relation- } \\
\text { ships established and } \\
\text { defined }\end{array}$ & $\begin{array}{l}\text { Relationships for water resource management formalised and } \\
\text { captured in the CMS }\end{array}$ & $\begin{array}{l}\text { Involve } \\
\text { Collaborate }\end{array}$ \\
\hline
\end{tabular}


information management and monitoring, and finances, the intentions of IWRM cannot be achieved.

\section{Part D: Integration strategy}

As is well recognised by now, IWRM requires collaboration. This is because many institutions are involved with various aspects of water-related activities, either directly or indirectly. Moreover, given our international agreements, the imperative for collaboration extends beyond our national borders.

\section{Taking the CMS as a series of tasks for public engagement}

In this section we will demonstrate how each part of the CMS, and hence IWRM in South Africa, can be broken down into tasks with which the public can engage. Each task is divided into a number of steps (taken from the procedures diagrams in the CMS guideline, DWAF, 2007). Table 3 summarises the tasks associated with each part and indicates the types of participation most appropriate for each. Table 4 describes issues related to HOW each step can be conducted.

Additionally, Table 3 identifies the different types of participation associated with each task. It is important to note that not every step associated with the task requires this particular level of participation. In the CMS guidelines (DWAF, 2006) a flow diagram is provided that indicates the appropriate level of participation at each stage of the process. In this paper we call for the development of participatory practices that are useful to the practitioner and that assist field staff with their facilitation. Table 3 does not describe aspects to WHO and WHEN for each step. This is the subject of an ongoing project.

Further to this goal, we demonstrate in the next section how each task can be broken down into a series of steps that follow in a specific sequence. For example the situation description and assessment (Part A) is broken down into 8 steps each with a clearly specified purpose, level of public participation and an expected outcome. An example is outlined in Table 4 where 4 of the 8 steps are described. In this way practitioners responsible for facilitating public participation are able to guide the process and the public is provided with a clear plan of procedure and outcomes.

Each section is taken directly from the CMS guideline and each task is developed in terms of steps (from the flow diagrams). The requisite level of public engagement is suggested and the 'how' for each task is reflected. The 10 sub-strategies for IWRM can be broken down into tables such as these in order to facilitate participatory practices. While this might seem an over-elaborate approach with excessive detail it has practical applicability in that it allows public participation facilitators to consciously plan in a logical and structured manner.

\section{Collating public participation into a strategy for the CMS}

The CMS guideline (DWAF, 2007) recognises that public engagement is an integral part of all components of the CMS. The guideline suggests that in order to formalise the public participation processes they should be collated into a sub-strategy for public engagement and capacity building. This integrative function is depicted in Fig. 2. Although this approach is open to the danger of over-structuring the public participation processes

\begin{tabular}{|c|c|c|c|c|}
\hline \multicolumn{5}{|c|}{$\begin{array}{l}\text { TABLE } 4 \\
\text { Example of the framework for public participation in Part A: Situation description showing } 4 \text { of the } \\
8 \text { steps with their level of participation and the expected outcome (STEEP factors refer to social, } \\
\text { technological, ecological, economic and political characteristics used to assess the status quo of } \\
\text { a particular catchment) }\end{array}$} \\
\hline $\begin{array}{l}\text { Activity \& Detail: } \\
\text { PART A -Situation } \\
\text { description }\end{array}$ & $\frac{8}{4}$ & $\begin{array}{c}\text { Level of } \\
\text { participation }\end{array}$ & How? & Outcome \\
\hline $\begin{array}{l}\text { Identify and engage } \\
\text { stakeholders and } \\
\text { institutions }\end{array}$ & 1 & है & $\begin{array}{l}\text { Communicate through media, letter CMC, CMF } \\
\text { and say that you are going to describe the } \\
\text { catchment in a holistic way to achieve } \\
\text { sustainability, equity and efficiency for the } \\
\text { catchment. }\end{array}$ & $\begin{array}{l}\text { Stakeholders informed } \\
\text { about their engagement }\end{array}$ \\
\hline $\begin{array}{l}\text { Describe STEEP for } \\
\text { status quo and projected } \\
\text { trend (i.e. min. } 2 \\
\text { scenarios) }\end{array}$ & 2 & 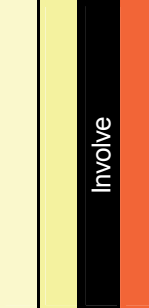 & $\begin{array}{l}\text { Use STEEP criteria: Social, technological, } \\
\text { economic, ecological and political and project } \\
\text { minimum two trends. Work together with the } \\
\text { public, the institutions, and CMC to describe the } \\
\text { catchment in a holistic way, using the best } \\
\text { available information. Involve in different } \\
\text { workshops for each criteria of STEEP. Involve } \\
\text { through information exchange and discussion. } \\
\text { Summarise STEEP in situation assessment } \\
\text { section of CMS. }\end{array}$ & $\begin{array}{l}\text { Described status quo for } \\
\text { the criteria: social, technical, } \\
\text { ecological, economic and } \\
\text { political in the catchment. } \\
\text { Minimum two projected } \\
\text { trends for the catchment. }\end{array}$ \\
\hline $\begin{array}{l}\text { Develop common under- } \\
\text { standing of catchment } \\
\text { including problems and } \\
\text { favourable aspects. } \\
\text { What is problematic, what } \\
\text { is favourable in the } \\
\text { catchment? }\end{array}$ & 3 & & $\begin{array}{l}\text { Collaborate through meetings with groups of the } \\
\text { different stakeholders, to find out the problems } \\
\text { and favourable aspects of the catchment by } \\
\text { discussing each STEEP criterion from Step } 2 \text {. } \\
\text { During the collaboration each stakeholder should } \\
\text { getan insight into the problems articulated by } \\
\text { other stakeholders. }\end{array}$ & $\begin{array}{l}\text { The catchment is } \\
\text { understood in entirety } \\
\text { and the problems and } \\
\text { favourable aspects of the } \\
\text { catchment are outlined. }\end{array}$ \\
\hline $\begin{array}{l}\text { Choose appropriate scale } \\
\text { for assessment (e.g. land } \\
\text { use, sub-catchment) }\end{array}$ & 4 & $\stackrel{\varepsilon}{0}$ & $\begin{array}{l}\text { Inform through communication after discussing } \\
\text { the possible scales. CMA sets the scale for the } \\
\text { assessment by using similar criteria for example: } \\
\text { land-use, mountains or industry. }\end{array}$ & $\begin{array}{l}\text { CMC are informed about } \\
\text { the scale for the } \\
\text { assessment. }\end{array}$ \\
\hline
\end{tabular}




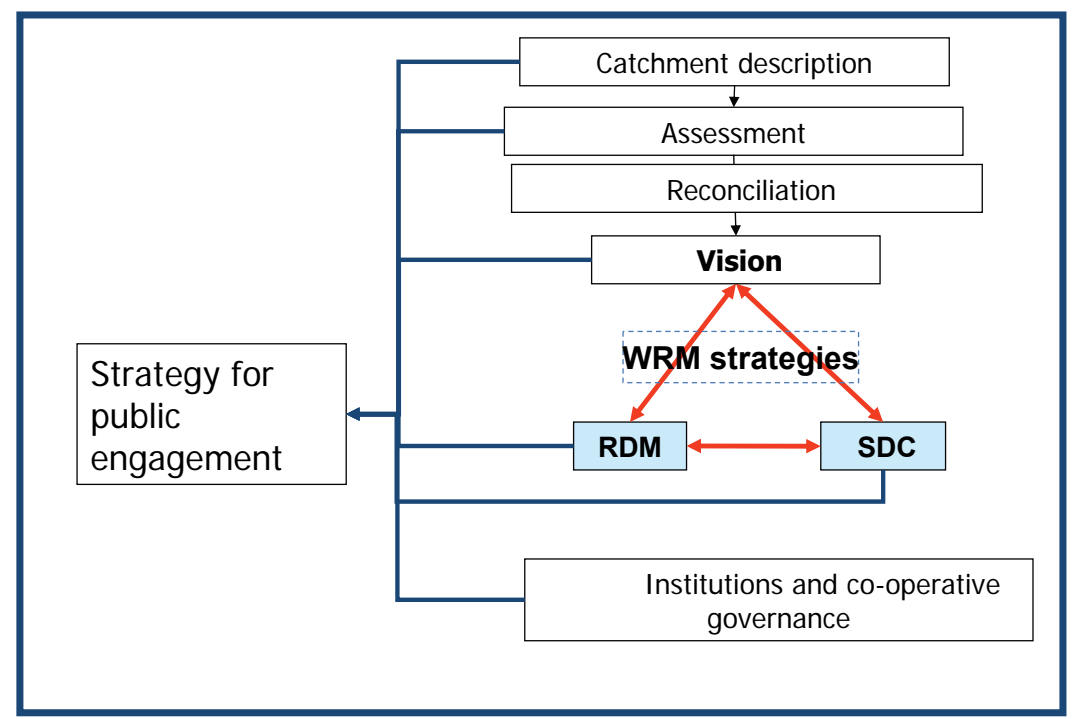

Figure 2

The sub-strategy for public engagement must draw on and collate the need for participation (and capacity development) associated with each of the components of the CMS.

at an early stage it can provide a valuable mechanism for ensuring that public participation processes do in fact take place and that the public can hold water management institutions accountable, should adequate public engagement not take place.

\section{Discussion}

The need to deepen the discourse on public participation in IWRM is critical for the development of an appropriate, practicable and functional approach. And while we recognise that this paper cannot present such an approach in its entirety we believe that the contents provide a step forward in the direction of developing the practices of participatory IWRM. We close with a number of points for discussion.

- The framework presented in this paper aims to provide practitioners with a concrete expression of IWRM through identifying specific tasks and distinguishing specific steps with designated outcomes. The aim is not to be over-formulaic but to provide some norms and standards with which multistakeholder groups can engage. Practical steps are currently being developed as part of an additional project.

- The framework is taken to be flexible with the intention that it can be adapted to specific contexts and the highly diverse water management areas of South Africa

- Public participation in IWRM is not a single-step process. This paper calls for the disaggregation of public participation into various types of participation using the IAP2 Spectrum. The levels of participation vary according to the specific stages of a water management task. The public is not expected to be participative in every step of the process. For example, the setting of the Reserve is a technical process that does not require public engagement. However, the public needs to be informed when a Reserve has been set so that an appropriate management class can be deliberated on. This demonstrates the 'integratedness' of all the IWRM tasks - the framework makes this explicit.

- Adopting a task and outcome-specific approach to IWRM provides an opportunity to better facilitate and manage the process. Using the framework for the development of the CMS means that the issues of sequence and procedure are clarified and that the public is in a better position to participate meaningfully.

- It is important to note that collaborative engagement is not expected in every instance and that it is reserved for specific steps in particular tasks. Collaborate engagement is costly and resource-intensive and not necessary for most steps in the CMS processes. It is important that stakeholders are aware of this so that the process can be focused and efficiently executed.

\section{Acknowledgements}

The authors are greatly indebted to the various individuals in the Department of Water Affairs and Forestry and other institutions who supported this work. Financial assistance from DWAF is acknowledged.

\section{References}

BURT J, DU TOIT D and NEVES D (2005) Learning about Participation: A Review of Participatory Water Resource Management. WRC Report No. K5/1434. Water Research Commission, Pretoria, South Africa.

BURT J (2005) A strategy for Participatory Water Resources Management in the Kat River Catchment. IWR, Rhodes University, Grahamstown, South Africa. WRC Report No. K9/1496. Water Research Commission, Pretoria, South Africa.

BURT J, McMASTER A, ROWNTREE K and BEROLD R (2007) Local Institutions for Water Governance: The Development of a Water User Association and Catchment Forum in the Kat River Valley, Eastern Cape. WRC Report No. TT 295/07. Water Research Commission, Pretoria, South Africa.

DU TOIT D, BURT J and POLLARD S (2005) A Task-Oriented Approach to Participation in IWRM. WRC Report No. K5/1434. Water Research Commission, Pretoria, South Africa.

DU TOIT D R (2005) Preparing people for integrated catchment management: a proposed learning alliance for the implementation of a new legal framework for water management in South Africa: 'reflexive learning in context'. In: Smits S, Fonseca C and Pels J (eds.) Learning Alliances for Scaling Up Innovative Approaches in the Water and Sanitation Sector. IRC International Water and Sanitation Centre, Delft, The Netherlands.

DEPARTMENT OF WATER AFFAIRS AND FORESTRY (DWAF) (1997) National Water Policy White Paper, April 1997. Pretoria, South Africa.DWAF (2000) Public Participation for Catchment Management Agencies and Water User Associations: Guide 4 in the CMA/WUA Guide Series.DWAF (2001a) Generic Public Participation Guidelines. Compiled by R van Jaarsveld. 
DWAF (2001b) Generic Communication Strategy for IWRM, DWAF/ DANCED.

DWAF (2001c) Capacity Building Overview Assessment Vol.1, Carl Bro a/s, IZNA Consortium.

DWAF (2001d) Capacity Building Overview Assessment Vol.2, Specific Capacity Building Requirements of Role-Players, Carl Bro a/s, IZNA Consortium.

DWAF (2004a) Guidelines for Stakeholder Participation in Integrated Water Resources Management in Water Management Areas In South Africa.

DWAF (2004b) Managing Public Participation: A Toolkit for Planning, Designing, Implementing, Monitoring and Evaluating Public Participation Processes Related to the Implementation of Integrated Water Resources Management with Particular Emphasis Upon the Inclusion of Marginalized Groups.

DWAF (2004c) National Water Resource Strategy. Pretoria, South Africa.

DWAF (2007) Guidelines for the Development of Catchment Management Strategies: Towards Equity, Efficiency and Sustainability in Water Resources Management ( $1^{\text {st }}$ edn.) by SR Pollard, D du Toit, J Reddy and T Tlou. Department of Water Affairs and Forestry, Pretoria, South Africa. Available from ww.dwaf.gov.za/documents/ other: catchment management.

INTERNATIONAL ASSOCIATION FOR PUBLIC PARTICIPATION (2000) Planning Effective Public Participation (Module 1). Denver USA.
POLLARD SR, PEREZ DE MENDIGUREN JC, JOUBERT A, SHACKLETON CM, WALKER P, POULTER T and WHITE M (1998) Save the Sand Phase 1 Feasibility Study: The Development of a Proposal for a Catchment Plan for the Sand River Catchment. Dept of Water Affairs \& Forestry, Pretoria, South Africa. 334 pp.

POLLARD S and DU TOIT D (2004) The Save the Sand Project: A Case Study. Both Ends, Netherlands.

POLLARD S and DU TOIT D (2008) Integrated water resource management in complex systems: How the catchment management strategies seek to achieve sustainability and equity in water resources in South Africa. Water SA 34 (6) 671-680.

REPUBLIC OF SOUTH AFRICA, DWAF (1998) National Water Act No 36 Government Printers, Pretoria, South Africa.

WRC (2003) Development of Protocols for Improving Catchment Management Through Enhanced Stakeholder Participation WRC Report No. 1062/1/03. Water Research Commission, Pretoria, South Africa.

WRC (2004a) Identification of the Critical Steps in Establishing and Ensuring the Sustainability and Transferability of Community Participation in ICM WRC Report No 866 and WRC Report No. 1157. Water Research Commission, Pretoria, South Africa.

WRC (2004b) Establishment of a WUA in the Kat River valley, Eastern Cape WRC 2003/4 No 1233.

WRC (2004c) Development of appropriate tools to support meaningful participation of the public at different levels of decision-making WRC Report No 1434. Water Research Commission, Pretoria, South Africa. 